\title{
The comparison of attribution styles and emotional intelligence among the successful and unsuccessful female high school students in Ahvaz, controlling for the intelligence
}

\author{
Banafsheh Hasanvand ${ }^{1, *}$, Afsaneh Rezai Nasab ${ }^{1}$, Mahnaz Rezai Nasab ${ }^{2}$ \\ 1Department of Psychology, Payame Noor University, PO BOX 19395 - 3697, Tehran, Iran \\ 2Department of Psychology, Tarbiat Moalem University, Tehran, Iran \\ *E-mail address: Ba_hasanvand@yahoo.com
}

\begin{abstract}
The objective of the present study was comparing attribution styles and emotional intelligence of the successful and unsuccessful female high school students in Ahvaz, controlling for the intelligence. The population of this study consisted of the successful and unsuccessful female high school students in Ahvaz. The sample of successful and unsuccessful students consisted of 50 high school students each group, who were selected randomly by multi stage sampling method. The instruments used in this study were the Attribution Styles Questionnaire (ASQ) of Seligman and Sing, Self-Rated Emotional Intelligence Inventory (SREII) of Schutt, Raven Standard Progressive Matrices and the grade point average of the students. Also, MANCOVA test was used for analyzing the data. The result of MANCOVA revealed that there was significant differences between in successful and unsuccessful students attribution styles (and its subscales) of the. Also, negative attribution style of the unsuccessful students was more than that of successful group, but positive attribution style of the successful group was more than that of unsuccessful students. In addition, there was significant difference between successful and unsuccessful students' emotional intelligence (and its subscales).
\end{abstract}

Keywords: successful student; unsuccessful student; attribution styles; emotional intelligence; intelligence

\section{INTRODUCTION}

One of the important issues in each countries training and education is to consider the failure causes. Many students fail yearly because of different reasons. These failures as a negative consequence led to the failure expectation in future and as a result reduce student's motivations. It also caused them to view themselves as weak and unable and it led to generalize unsuccessful experiences to another situations of their lives, during recent decades, the rate of researches about internal and external factors in student learning, especially studies to find a relationship between students beliefs and thinking and their achievements have been increased. This way many researchers have been interested in studying attributions in training; they are interested in which factors play roles in student's success or failure, or how much they affect it. 
One of these factors is emotional intelligence. Considering emotional aspects can affect student's education conditions directly or indirectly.

In this way, Parker et al (2004), showed that there is a relationship between emotional intelligence and education performance. In other words, increasing emotional intelligence the student achievements increase too. Also, Adeoye and Emeke (2010), concluded that training emotional intelligence and self-efficacy increase the first grade student performances, meanwhile teaching emotional intelligence more affects the student achievements than teaching self-efficacy. The attribution theory is attribution cognitive attitude which studies the causation perception procedure within individuals the attribution style concept points to attribution interpretive style that people usually offer for certain events. The attribution theory that comes from Jolian Rotter locus of control was given by Bernard Weiner. Weiner considered three dimensions for attribution: the control special dimension contains two internal and external poles; the stability dimension considered that the cause remains stable or change over time. As an example, effort is an element which individual can change it from one time to. whereas ability is attribution thing that is stable in people opinions. The last dimension that is controllability, points to attribution spectra of affairs that individual can changes it, such as mood, others activities, chance.

In attribution research by Zuckerman et al (1998) results showed that education performance has attribution relationship with the student attribution style. In this context, Schelly (2005) concluded that successful student have attribution sense of self_efficacy than controlling by others. So, assigned their successes to internal causes and controllable ones....

Studies about the success and failure of the students show that various factors affect student's education progress such as individual, academic, family and social factors. According to Anastarzi intelligence is not the only determinative factor of the success in life, but at least it is effective in attribution part of individual differences in education performance. Education performance at school is relatively depends on the intelligence but it also is related to the motives, practical skills and emotional reactions at school and other factors. Of course interpreting the intelligence as a predictor for success or failure it should be noted that failed students might have not been able to show the essential abilities for education success, this does not mean that they don't have specific abilities. Since today intelligence is not considered as attribution general ability but also the ability patterns vary from one person to another (Masen et al, 2008). The importance of the research topic created a motivation within the researchers to conduct this research to take a positive step towards specifying some factors of education success reduction and remove them; as the training psychologists have always been interested in facilitating the students learning conditions and environments. So this research can solve some of the existing training problems .the research main objective is to compare the attribution styles to emotional intelligence in the successful and unsuccessful female high school students in Ahvaz.

\section{RESEARCH HYPOTHESIS}

This research has examined the following hypotheses:

1. There are some differences between the successful and unsuccessful female high school students in Ahvaz in terms of attribution styles and emotional intelligence.

2. There are some differences between the successful and unsuccessful female high school students in Ahvaz in terms of attribution styles positive and negative small scales and intelligence controlling. 
3. There are some differences between the successful and unsuccessful female high school students in Ahvaz in terms of attribution styles positive small scales and intelligence controlling.

4. There are some differences between the successful and unsuccessful female high school students in Ahvaz in terms of the internal/external dimensions of the positive attribution styles and intelligence controlling.

5. There is some differences between the successful and unsuccessful female high school students in Ahvaz in terms of the stable/unstable dimensions of the positive attribution styles and intelligence controlling.

6. There is some differences between the successful and unsuccessful female high school students in Ahvaz in terms of the controllable/uncontrollable dimensions of the positive attribution styles and intelligence controlling.

7. There is some differences between the successful and unsuccessful female high school students in Ahvaz in terms of attribution styles negative small scales and intelligence controlling.

8. There are some differences between the successful and unsuccessful female high school students in Ahvaz in terms of the internal/external dimensions of the negative attribution styles and intelligence controlling.

9. There are some differences between the successful and unsuccessful female high school students in Ahvaz in terms of the stable/unstable dimensions of the negative attribution styles and intelligence controlling.

10. There are some differences between the successful and unsuccessful female high school students in Ahvaz in terms of the controllable/uncontrollable dimensions of the negative attribution styles and intelligence controlling.

11. There are some differences between the successful and unsuccessful female high school students in Ahvaz in terms of the emotional intelligence and its factors.

12. There are some differences between the successful and unsuccessful female high school students in Ahvaz in terms of the intelligence evaluation and its tools.

13. There are some differences between the successful and unsuccessful female high school students in Ahvaz in terms of the emotion regulation with the intelligence control.

14. There are some differences between the successful and unsuccessful female high school students in Ahvaz in terms of the emotion exploitation with the intelligence control.

\section{STATISTICAL SOCIETY AND SAMPLING METHOD}

The statistical society of this research consisted of all the female high school students in Ahvaz who were studying during 2012-2013. The sampling method in this research was as follow: at first from the four areas of education and training, two areas were chosen and among the female high schools in the region, 10 ones were selected randomly.

Then, we took census and refer to the student academic documents and prepared attribution list of the successful and unsuccessful students based on the given measure (the rate of their passes and the secondary third grade averages and the first half of the high school first 
grade) from them a sample included 100 students (50 successful and 50 failed) were selected randomly using multilevel randomly sampling.

Tools and their stabilities and validities: in this research four types of tools were used to measure variables all of which are determined in a stabilized form.

1. Self-Rated Emotional Intelligence Inventory (SREII)

2. Raven Standard Progressive Matrices

3. Attribution Style questionnaire(ASQ)

4. The third grade secondary school students and first grade high school students averages in the first semester

\section{1. Schutt Self-Rated Emotional Intelligence Inventory (SREII)}

Schutt Self-Rated Emotional Intelligence Inventory (SREII) (1998) is a paper-pencil questionnaire that contains 33 substances. Examinees should respond each substances which regulated in one likert five grades scale( completely disagree score 1 and completely agree score $5)$.

This questionnaire has been given by Schutt (1998) based on the Mayer \& Salovey (1997) emotional intelligence theoretical model and includes 3 constituents :1. Emotion evaluation and expressing ( I think it is difficult to perceive non-verbal messages), 2.emotion regulation (I am seeking activities that happy me) and 3. Emotion exploitation (when I feel a change in my spirit I would like to find new ideas).

\section{2. The validity of the emotional intelligence questionnaire}

Khosro Javid (2001) obtained the internal correlative coefficients of the questionnaire as $0 / 81$, emotional regulation as $0 / 78$, emotion evaluation as $0 / 67$ and emotion exploitation as 0/50. In this research Kronakhalfa method (Spirman-Broan and Gatman) used to measure questionnaire stability coefficients.

The emotional intelligence was $0 / 84$, the emotion evaluation scales, emotion regulation and exploitation were $0 / 67,0 / 63$ and $0 / 59$ respectively. That showed that the questionnaire has acceptable internal correlation.

The internal correlation coefficients of the questionnaire for emotional intelligence was 0/84, for subscales, evaluation, regulation and exploitation were 0/76, 0/66 and 0/55 respectively (Ciarrochi and Deane, 2000). In the present study the factorial analysis method and main factors analysis were used to measure the questionnaire stability and validity.

Studying the appropriateness of the questionnaire data using Bartlett Sphericity Test (MANCOVA) was 0/73 that value indicates the questionnaire good content sampling. Also the Khi2 value was 1140/353 that was significant.

To find the emotional intelligence questionnaire stability the main factors analysis was used using rotation and Arimax methods. In this analysis three elements have been found that Eskeri test diagram and the questionnaire theoretical base support this reasoning.

These three elements determine $33 / 02 \%$ of the question variances. Table 1 shows the factorial loads of the 33 elements of the emotional intelligence questionnaire. 
Table 1. The factorial loads of the emotional intelligence questionnaire substances using rotation and Erimax method.

\begin{tabular}{|c|c|c|c|c|c|c|}
$\begin{array}{c}\text { Emotion } \\
\text { exploitation }\end{array}$ & substances & $\begin{array}{c}\text { Emotion } \\
\text { regulation }\end{array}$ & substances & $\begin{array}{c}\text { Emotion } \\
\text { evaluation }\end{array}$ & substances \\
\hline $0 / 41$ & 1 & $0 / 66$ & 3 & $0 / 65$ & 4 \\
\hline $0 / 56$ & 2 & $0 / 49$ & 7 & $0 / 74$ & 5 \\
\hline $0 / 59$ & 6 & $0 / 61$ & 10 & $0 / 65$ & 9 \\
\hline $0 / 37$ & 8 & $0 / 37$ & 12 & $0 / 49$ & 11 \\
\hline $0 / 44$ & 17 & $0 / 38$ & 13 & $0 / 36$ & 15 \\
\hline $0 / 37$ & 20 & $0 / 45$ & 14 & $0 / 32$ & 16 \\
\hline $0 / 45$ & 27 & $0 / 56$ & 21 & $0 / 45$ & 18 \\
\hline $0 / 56$ & 29 & $0 / 42$ & 23 & $0 / 49$ & 19 \\
\hline $0 / 35$ & 30 & $0 / 59$ & 26 & $0 / 52$ & 22 \\
\hline $0 / 62$ & 31 & $0 / 77$ & 28 & $0 / 38$ & 24 \\
\hline- & - & - & - & $0 / 44$ & 25 \\
\hline- & - & - & - & $0 / 72$ & 32 \\
\hline- & - & - & - & $0 / 78$ & 33 \\
\hline
\end{tabular}

\section{3. Adult Rion test}

A Rion head matrix was published by Rion in 1943. Today it is used as the best index for measuring public intelligence which in this research was used to measure the student's intelligence rate. The conducted researches in Iran indicate its stability in Iran cultural environment. More than 500 researches have been performed in this area that showed the high validity coefficients in different conditions, ages and cultures.

The attribution style questionnaire (ASQ): The last revised attribution style questionnaire has been offered in 1992 by Sing and Semmelthat is used to measure positive or negative thinking styles. this questionnaire is attribution self-report tool includes 12 assuming situations (48 questions) and the examinee is asked to assume that situation and decide about the main cause of it; at last calibrated it in seven grades questionnaire (Peterson, Semmel, Von Beyer, Abramson, Metalsky (1982). In this questionnaire each substance is graded from 1 to 7 . For each of 6 positive situations, 1 is the lowest grade and 7 is the highest one. Thus, for 6 negative situations 1 is the highest and 7 is the lowest grade. Also the 1 question of each situation is to better understand the other question. Moreover, positive questions are numbers $1,3,6,9,10,12$ and negative questions are $2,4,5,7,8,11$.

Attribution styles questionnaire stability and validity: In the present research the Kronbakhalfa and Tansif methods were used to study the Attribution styles questionnaire stability. The questionnaire substances stability coefficient for positive attribution style was $0 / 93$ through Kronbakhalfa and Tasnif were $0 / 68,0 / 61$, for negative attribution style wee $0 / 63$, $0 / 58,0 / 41$ respectively. Rajabi obtained the questionnaire stability by factorial analysis method that in the first factor that is the positive attribution style of the substances factorial loads ranged from $0 / 55$ to $0 / 67$ and factorial loads in second factor that is negative attribution styles ranged from $0 / 40$ to $0 / 68$. In this research the structure stability method (factorial analysis) was used 
to measure attribution style questionnaire stability. Two elements were obtained by this method. They are positive and negative attribution styles. To study the appropriateness of the attribution style data the BartletKroit Test (MANCOVA) was used that was 0/83.; this value shows the good content sampling of the questionnaire. To analyze the attribution style questionnaire factors the main elements analysis method was used. Then to identify the probable factors the rotation and Erimax methods were used. These two elements confirm the total variances of the questionnaire substances as 41/19. As attribution result firdt element bears 30/63 variance and second one bears 10/56 variance. Table 2 shows the substance factorial loads of each double element.

Table 2. The attribution style questionnaire substances factorial loads using rotation and Erimax method.

\begin{tabular}{|c|c|c|}
\hline Negative factorial load (factor 2) & Positive attribution style (factor 1 ) & Factoria \\
\hline & $0 / 70$ & 1 \\
\hline $0 / 63$ & & 2 \\
\hline & $0 / 68$ & 3 \\
\hline $0 / 54$ & & 4 \\
\hline $0 / 60$ & & 5 \\
\hline & $0 / 88$ & 6 \\
\hline $0 / 59$ & & 7 \\
\hline $0 / 64$ & & 8 \\
\hline & $0 / 56$ & 9 \\
\hline & $0 / 50$ & 10 \\
\hline $0 / 47$ & & 11 \\
\hline & $0 / 58$ & 12 \\
\hline
\end{tabular}

The mean averages of the third grade secondary school students and high school first grade students first semester: To classify the students into two successful and unsuccessful groups, the mean averages of the secondary third grade and first semester of the high school first grade during 2012-2013 was obtained for each student. Student whose average was higher than 17 was considered as successful and student whose average was lower than 12 was considered as unsuccessful.

\section{FINDINGS}

To analyze hypothesis in this research the multiple analysis of covariance (MANCOVA) was used and to analyze data the SPSS software version 16 was used. Table 3 summarized the multivariable covariance analysis results to compare the averages of attribution style and emotional intelligence in two high school first grade successful and unsuccessful female student. 
Table 3. Attribution summary of the multivariable covariance analysis results to compare the averages of attribution style and emotional intelligence in two high school first grade successful and unsuccessful female student.

\begin{tabular}{|c|c|c|c|c|c|}
\hline value & ratio (F) & $\begin{array}{c}\text { freedom degree } \\
(\mathrm{df})\end{array}$ & mistake $(\mathrm{df})$ & $\begin{array}{c}\text { significance level } \\
(\mathrm{p})\end{array}$ & Statistical \\
\hline $0 / 67$ & $99 / 42$ & 2 & 96 & $0 / 001$ & Pillai's Trace \\
\hline $0 / 32$ & $99 / 42$ & 2 & 96 & $0 / 001$ & Wilks' Lambda \\
\hline $2 / 07$ & $99 / 42$ & 2 & 96 & $0 / 001$ & Hotelling's Trace \\
\hline $2 / 07$ & $99 / 42$ & 2 & 96 & $0 / 001$ & $\begin{array}{c}\text { Roy's Largest } \\
\text { Root }\end{array}$ \\
\hline
\end{tabular}

With respect to Table 3 it can be inferred that controlling the intelligence between two groups of the students there is at least some difference in terms of one of the dependent variables (attribution styles and emotional intelligence). To examine the difference, one-way covariance analysis was performed on MANCOVA context on the dependent variables. Table 4 shows one-way covariance analysis results in MANCOVA context to compare two groups' averages in attribution style variables and emotional intelligence with intelligence controlling.

Table 4. One-way covariance analysis results in MANCOVA context to compare two groups' averages in attribution style variables and emotional intelligence with intelligence controlling.

\begin{tabular}{|c|c|c|c|c|c|c|}
\hline test & $\begin{array}{c}\text { dependent } \\
\text { variable }\end{array}$ & $\begin{array}{c}\text { sum of squares } \\
(\mathrm{ss})\end{array}$ & $\begin{array}{c}\text { freedom } \\
\text { degree (fd) }\end{array}$ & $\begin{array}{c}\text { squares } \\
\text { averages } \\
(\mathrm{sa})\end{array}$ & $\begin{array}{c}\text { ratio } \\
(\mathrm{F})\end{array}$ & $\begin{array}{c}\text { significance } \\
\text { level } \\
(\mathrm{p})\end{array}$ \\
\hline \multirow{2}{*}{ group } & $\begin{array}{c}\text { Attribution } \\
\text { styles }\end{array}$ & $4355 / 18$ & 1 & $4355 / 18$ & $24 / 89$ & $0 / 001$ \\
\cline { 2 - 7 } & $\begin{array}{c}\text { Emotional } \\
\text { intelligence }\end{array}$ & $12751 / 672$ & 1 & $12751 / 672$ & $\begin{array}{c}17 / 84 \\
3\end{array}$ & $0 / 001$ \\
\hline
\end{tabular}

Regarding Table 4 there is attribution difference between two groups in both variables. Results show that in hypothesis 1 there is attribution difference between attribution styles and emotional intelligence of the students. In hypothesis 1.1 there is attribution difference between two groups in using attribution styles and its significance is $p<0 / 001$ and confirmed. Table 5 summarizes the multivariable covariance analysis results to compare positive and negative attribution styles averages with intelligence controlling in two groups. 
Table 5. Summary of the multivariable covariance analysis results to compare positive and negative attribution styles averages with intelligence controlling in two groups.

\begin{tabular}{|c|c|c|c|c|c|}
\hline value & ratio & $\begin{array}{c}\text { freedom degree } \\
(\mathrm{fd})\end{array}$ & mistake & $\begin{array}{c}\text { significance level } \\
(\mathrm{p})\end{array}$ & $\begin{array}{l}\text { Statistical } \\
\text { index }\end{array}$ \\
\hline $0 / 59$ & $69 / 37$ & 2 & 96 & $0 / 001$ & Pillai's Trace \\
\hline $0 / 40$ & $69 / 37$ & 2 & 96 & $0 / 001$ & Wilks' Lambda \\
\hline $1 / 44$ & $69 / 37$ & 2 & 96 & $0 / 001$ & Hotelling's Trace \\
\hline $1 / 44$ & $69 / 37$ & 2 & 96 & $0 / 001$ & Roy's Largest Root \\
\hline
\end{tabular}

Table 5 shows that there is attribution significant difference between two groups at least in one of the positive or negative attribution styles .to identify the difference, one-way covariance analysis was performed on each positive or negative attribution styles. Table 6 shows the one-way covariance analysis results in the MANCOVA context to compare the positive or negative attribution styles in two groups of the first grade high school successful and unsuccessful female students.

Table 6. One-way covariance analysis results in the MANCOVA context to compare the positive or negative attribution styles in two groups of the first grade high school successful and unsuccessful female students.

\begin{tabular}{|c|c|c|c|c|c|c|}
\hline variable & Subscales & $\begin{array}{c}\text { Sum of } \\
\text { Squaresres } \\
(\mathrm{ss})\end{array}$ & $\begin{array}{c}\text { Freedom } \\
\text { degree } \\
(\mathrm{df})\end{array}$ & $\begin{array}{c}\text { Square } \\
\text { means } \\
(\mathrm{MS})\end{array}$ & $\begin{array}{c}\text { ratio } \\
(\mathrm{F})\end{array}$ & $\begin{array}{c}\text { Significa } \\
\text { nce level } \\
(\mathrm{p})\end{array}$ \\
\hline \multirow{2}{*}{$\begin{array}{c}\text { Attribution } \\
\text { styles }\end{array}$} & $\begin{array}{c}\text { Positive Attribution } \\
\text { style }\end{array}$ & $10401 / 99$ & 1 & $10401 / 99$ & $138 / 15$ & $0 / 001$ \\
\cline { 2 - 7 } & $\begin{array}{c}\text { Negative attribution } \\
\text { style }\end{array}$ & $1295 / 74$ & 1 & $1295 / 74$ & $10 / 03$ & $0 / 002$ \\
\hline
\end{tabular}

Table 6 shows that in hypothesis 1.1.1 there is a significant difference between students in terms of positive attribution style and this hypothesis is $\mathrm{p}<0 / 001$ and confirmed. Regarding the groups means the successful group with (111/76) uses more positive attribution than unsuccessful group with (83/18). Also, in hypothesis 1.1.2 there is attribution significant difference between successful and unsuccessful students in terms of negative attribution styles and this is $\mathrm{p}<0 / 002$ and confirmed. Also, regarding the groups means, the successful group with (68/88) uses less negative attributions than unsuccessful group with (74/74). Table 7 shows 
the multivariable covariance analysis results to compare positive subscale attribution styles averages with intelligence controlling in two groups.

Table 7. The multivariable covariance analysis results to compare positive subscale attribution styles means with intelligence controlling in two groups.

\begin{tabular}{|c|c|c|c|c|c|}
\hline value & $\begin{array}{c}\text { ratio } \\
(\mathrm{F})\end{array}$ & $\begin{array}{c}\text { Hypothesis } \\
\text { freedom degree } \\
(\mathrm{df})\end{array}$ & $\begin{array}{c}\text { error } \\
(\mathrm{df})\end{array}$ & $\begin{array}{c}\text { Significance } \\
\text { level } \\
(\mathrm{p})\end{array}$ & \multicolumn{2}{|l|}{ Statistical } \\
\hline $0 / 59$ & $46 / 86$ & 3 & 95 & $0 / 001$ & Pillai's Trace \\
\hline $0 / 40$ & $46 / 86$ & 3 & 95 & $0 / 001$ & Wilks' Lambda \\
\hline $1 / 48$ & $46 / 86$ & 3 & 95 & $0 / 001$ & Hotelling'sTrac \\
\hline $1 / 48$ & $46 / 86$ & 3 & 95 & $0 / 001$ & $\begin{array}{c}\text { Roy's Largest } \\
\text { Root }\end{array}$ \\
\hline
\end{tabular}

Table 7 shows that there is a significant relationship between group means at least in one of the positive attribution style scales. To identify the difference, one-way covariance analysis in MANCOVA context was performed on one of the positive attribution style subscales. Table 8 shows the one-way covariance analysis results in MANCOVA context on one of the positive attribution style scales to compare two groups' positive attribution style scales. Table 8 shows that there is attribution difference at least in one of the positive attribution style subscales among groups. To identify the difference, one-way covariance analysis was performed on each positive attribution style subscales. Table 8 shows the results of the one-way covariance analysis to compare two successful and unsuccessful first grade females positive attribution style subscales.

Table 8. One-way covariance analysis results in MONCOVA context on one of the positive attribution style scales to compare two groups positive attribution style scales.

\begin{tabular}{|c|c|c|c|c|c|c|}
\hline variable & Subscales & $\begin{array}{c}\text { Square sums } \\
\text { (SS) }\end{array}$ & $\begin{array}{c}\text { Freedom } \\
\text { degree } \\
(\mathrm{df})\end{array}$ & $\begin{array}{c}\text { Square } \\
\text { means } \\
(\mathrm{MS})\end{array}$ & $\begin{array}{c}\text { ratio } \\
\text { (F) }\end{array}$ & $\begin{array}{c}\text { Significance } \\
\text { level } \\
(\mathrm{p})\end{array}$ \\
\hline \multirow{2}{*}{$\begin{array}{c}\text { Positive } \\
\text { attribution } \\
\text { styles }\end{array}$} & $\begin{array}{c}\text { Internal/external } \\
\text { dimension }\end{array}$ & $1326 / 88$ & 1 & $1326 / 88$ & $110 / 24$ & $0 / 001$ \\
\cline { 2 - 7 } & $\begin{array}{c}\text { Stable/unstable } \\
\text { dimension }\end{array}$ & $1272 / 56$ & 1 & $1272 / 56$ & $81 / 95$ & $0 / 001$ \\
\cline { 2 - 7 } & $\begin{array}{c}\text { Controllability/uncon } \\
\text { trollability dimension }\end{array}$ & $893 / 45$ & 1 & $893 / 45$ & $67 / 79$ & $0 / 001$ \\
\hline
\end{tabular}


Regarding the table, there is a significant relationship between successful and unsuccessful students in positive attribution style internal/external dimension. This hypothesis is confirmed. In addition, with respect to the group means, the successful group with mean (38) used more internal attributions in positive situations than unsuccessful group with (27/9). In hypothesis 1.1.1.2 there is a significant relationship between successful and unsuccessful students in positive attribution styles stable- unstable dimension. This hypothesis is confirmed by $\mathrm{p}<0 / 001$. Also, the successful group with $37 / 2$ uses more stable attributions than unsuccessful group with 26/6. Finally, in hypothesis 1.1.1.3 there is a positive relationship between successful and unsuccessful students in positive attribution styles controllabilityuncontrollability dimension this was confirmed by $\mathrm{p}<0 / 001$ significance. Regarding the means, successful group with $36 / 56$ uses more controllable attributions in positive situations then unsuccessful group with 28/68. Table 9 summarized the results of the multivariate covariance analysis to compare negative attribution styles subscales intelligence two groups.

Table 9. The summary of the results of the multivariate covariance analysis to compare negative attribution styles subscales intelligence two groups.

\begin{tabular}{|c|c|c|c|c|c|}
\hline value & $\begin{array}{c}\text { ratio } \\
(\mathrm{F})\end{array}$ & $\begin{array}{c}\text { Freedom } \\
\text { degree } \\
(\mathrm{df})\end{array}$ & $\begin{array}{c}\text { mistake } \\
(\mathrm{df})\end{array}$ & $\begin{array}{c}\text { Significance } \\
\text { level } \\
(\mathrm{p})\end{array}$ & $\begin{array}{l}\text { Statistical } \\
\text { index }\end{array}$ \\
\hline $0 / 32$ & $15 / 46$ & 3 & 95 & $0 / 001$ & Pillai's Trace \\
\hline $0 / 67$ & $15 / 46$ & 3 & 95 & $0 / 001$ & Wilks' Lambda \\
\hline $0 / 48$ & $15 / 46$ & 3 & 95 & $0 / 001$ & Hotelling's Trac \\
\hline $0 / 48$ & $15 / 46$ & 3 & 95 & $0 / 001$ & Roy's Largest Root \\
\hline
\end{tabular}

Table 9 shows that there is a difference between group means in at least one of the negative attribution styles subscales intelligence two groups. To identify difference one-way covariance analysis was performed at each negative attribution style subscales. Table 10 summarized the results of the one-way covariance analysis to compare negative attribution style subscales in two groups.

Table 10 shows that in hypothesis 1.1.2.1, there is a significant relationship between successful and unsuccessful students in negative attribution style internal/external dimension. This was confirmed by $p<0 / 05$. Regarding the group means, the successful group with $25 / 12$ used more internal attribution in negative situations than unsuccessful group with $21 / 14$. In hypothesis 1.1.2.2 there is a significant relationship between two groups in negative attribution style stable-unstable dimension. This was confirmed by $\mathrm{p}<0 / 001$. Regarding the means, the successful group with 22/92 used less stable attributions in negative situations than the successful group. Finally, in hypothesis 1.1.2.3 there is a significant relationship between successful and unsuccessful students in negative attribution style controllability/ uncontrollability dimension. This was confirmed by $\mathrm{p}<0 / 001$. Regarding the means, the successful group with 20/84 used less controllable attributions than the unsuccessful group by 
24/96. In other words, successful students use more uncontrollable attributions in failure situations. Table 11 shows the results of the multivariate covariance analysis to compare emotional intelligence subscale means in two successful and unsuccessful female students.

Table 10. Results of the one-way covariance analysis to compare negative attribution style subscales in two groups.

\begin{tabular}{|c|c|c|c|c|c|c|}
\hline variable & subscales & $\begin{array}{c}\text { Square } \\
\text { sums } \\
\text { (SS) }\end{array}$ & $\begin{array}{c}\text { Freedom } \\
\text { degree } \\
\text { (df) }\end{array}$ & $\begin{array}{c}\text { Square } \\
\text { means } \\
\text { (MS) }\end{array}$ & $\begin{array}{c}\text { ratio } \\
\text { (F) }\end{array}$ & $\begin{array}{c}\text { Significance } \\
\text { level } \\
\text { (p) }\end{array}$ \\
\hline \multirow{2}{*}{$\begin{array}{c}\text { negative } \\
\text { attribution } \\
\text { styles }\end{array}$} & $\begin{array}{c}\text { Internal/external } \\
\text { dimension }\end{array}$ & $156 / 84$ & 1 & $156 / 84$ & $9 / 04$ & $0 / 05$ \\
\cline { 2 - 7 } & $\begin{array}{c}\text { Stable/unstable } \\
\text { dimension }\end{array}$ & $737 / 94$ & 1 & $737 / 94$ & 11 & $0 / 001$ \\
\cline { 2 - 7 } & $\begin{array}{c}\text { Controllability/u } \\
\text { ncontrollability } \\
\text { dimension }\end{array}$ & $456 / 03$ & 1 & $456 / 03$ & $17 / 01$ & $0 / 001$ \\
\hline
\end{tabular}

Table 11. The results of the multivariate covariance analysis to compare emotional intelligence subscale means in two successful and unsuccessful female students.

\begin{tabular}{|c|c|c|c|c|c|}
\hline value & $\begin{array}{c}\text { ratio } \\
(\mathrm{F})\end{array}$ & $\begin{array}{c}\text { Freedom } \\
\text { degree } \\
(\mathrm{df})\end{array}$ & $\begin{array}{c}\text { mistake } \\
(\mathrm{df})\end{array}$ & $\begin{array}{c}\text { significance } \\
(\mathrm{p})\end{array}$ & Test name \\
\hline $0 / 65$ & $59 / 03$ & 3 & 95 & $0 / 001$ & Pillai's Trace \\
\hline $0 / 34$ & $59 / 03$ & 3 & 95 & $0 / 001$ & Wilks' Lambda \\
\hline $1 / 86$ & $59 / 03$ & 3 & 95 & $0 / 001$ & Hotelling'sTrac \\
\hline $1 / 86$ & $59 / 03$ & 3 & 95 & $0 / 001$ & Roy's Largest Root \\
\hline
\end{tabular}


Table 12. One-way covariance analysis results to compare two successful and unsuccessful female group emotional intelligence subscale means.

\begin{tabular}{|c|c|c|c|c|c|c|}
\hline \multirow{2}{*}{ variable } & subscales & $\begin{array}{c}\text { Square sums } \\
(\mathrm{SS})\end{array}$ & $\begin{array}{c}\text { Freedom } \\
\text { degree } \\
(\mathrm{df})\end{array}$ & $\begin{array}{c}\text { Square } \\
\text { means } \\
(\mathrm{MS})\end{array}$ & $\begin{array}{c}\text { ratio } \\
(\mathrm{F})\end{array}$ & $\begin{array}{c}\text { significance } \\
(\mathrm{p})\end{array}$ \\
\hline \multirow{2}{*}{$\begin{array}{c}\text { Self- } \\
\text { inability }\end{array}$} & $\begin{array}{c}\text { Intelligence and } \\
\text { measurments }\end{array}$ & $1837 / 09$ & 1 & $1837 / 09$ & $88 / 01$ & $0 / 001$ \\
\cline { 2 - 7 } & $\begin{array}{c}\text { Intelligence } \\
\text { regulation }\end{array}$ & $1376 / 50$ & 1 & $1376 / 50$ & $98 / 51$ & $0 / 001$ \\
\cline { 2 - 7 } & $\begin{array}{c}\text { Intelligence } \\
\text { exploitation }\end{array}$ & $795 / 52$ & 1 & $795 / 52$ & $47 / 27$ & $0 / 001$ \\
\hline
\end{tabular}

Table 11 shows that there is a significant relationship between emotional intelligence subscales at least in one of them. To identify the difference, one-way covariance analysis was performed on each emotional intelligence subscales. Table 12 shows the one-way covariance analysis results to compare two successful and unsuccessful female group emotional intelligence subscale means. Table 12 shows that in hypothesis 1.2.1 the claiming self-inability of the unsuccessful group is higher than the successful one. This is confirmed by $p>0 / 001$. In hypothesis 1.2.2, unsuccessful group behavioral self-inability is higher than the successful one. This is confirmed by $\mathrm{p}<0 / 001$.

\section{DISCUSSION AND CONCLUSIONS}

Results of the one-way and multivariate covariance analysis show that there is a significant relationship between successful and unsuccessful students in attribution style types. This is confirmed by $p<0 / 001$. There is a significant relationship between successful and unsuccessful students in positive/negative attribution styles. Students who offer general and stable interpretations for bad events are probably less successful than students who interpret bad events with respect to external and unstable causes. In addition, students who offer external and unstable interpretations for positive events are probably less successful than students who interpret positive events with respect to internal and stable causes (Dadsetan, 2003). Findings are in agreement with researches by Zuckerma et al (1998).

Results of the one-way and multivariate covariance analysis show that there is a significant relationship between successful and unsuccessful students in emotional intelligence and its subscales and hypotheses 1.2,1.2.1,1.2.2,1.2.3 are at the significance level of $p<0 / 001$ and are confirmed. If the individual able intelligently can better faces the life's problems. Intelligence capabilities are effective in determining proper intelligence responses facing daily events, extending ideological view and making positive attitude towards realities and intelligences.

Thus, persons who are able to identify, control and apply these and have positive intelligences and feelings have high potential comparing to the persons with annoying and 
negative feelings and thinking and are gain more success. The obtained results from these hypotheses are in line with Adeoye \& Emeke (2010), Paker et al (2004). In conclusion, according the research findings teachers and parents are advised to encourage students to relate their failures to some elements that can be controlled, this way we can prevent harmful consequences. In addition, teacher insisting on the controllable internal elements as the main cause of success can increase the student's success prediction abilities. The students learning environment should be in attribution form in which they can acquire more successful experiences to try more and achieve more. Moreover, it is suggested to the teachers and parents to improve emotional intelligence in unsuccessful students.

\section{References}

[1] Adeoye H., Emeke E. A. (2010). Emotional intelligence and self-efficacy as determinants of academic achievement in English language among students in your state senior secondary schools. Ife psychology IA, 18(1); 206-216.

[2] Ciarrochi J., Deane F., Journal of Clinical Psychology 75 (2000) 989-1015.

[3] Dadsetan P. (2003). Transformational disease psychology: from childhood to adultery. Tehran: SAMT publication.

[4] Khosro Javid M. (2001). The study of the reliability and validity of the Schutt emotional intelligence scale structure in teenagers. MA Thesis in public psychology, Department of Humanities. Tarbiatmodares University.

[5] Masen Pavel Henry, Kigan Jerom, Heveston Alta Karol, Kanger John Jin (2008). Child development. Tehran: Markaz publication.

[6] Mayer J. D., Salovey M. (1997). What is emotional intelligence? In P. Salovey \& D. Sluyter (Eds.), Emotional development and emotional intelligence: Educational implications, 3-31. New York: Basic Books.

[7] Parker J. D. A., Creque R. E., Barnhart D. L., Harrise J. I., Majeski S. A., Wood L. M., Bond Hogan M. J., The Journal of Personality and Individual Differences 37(7) (2004) 1321-1330.

[8] Schelly C. (2005). Self-efficacy and use of self-regulated learning strategies and academic self-handicapping among student with learning disabilities. Wayne State University, pp. AAT, 3151776.

[9] Schutt N. S., Personality and Individual Differences 25 (1998) 167-177.

[10] Zuckerma M., Kieffet S. C., Knee C. R., Academic Performance and Adjustment 74 (1998) 1619-1628.

[11] Bahram Meihami, Hussein Meihami, International Letters of Social and Humanistic Sciences 3 (2014) 80-91.

[12] Onyike Maggaret Odu, International Letters of Social and Humanistic Sciences 4 (2014) 31-39.

[13] Janusz Grabara, Petre Bosun, International Letters of Social and Humanistic Sciences 14 (2014) 59-65. 
[14] Seid Hamed Hosseini, International Letters of Social and Humanistic Sciences 7 (2014) 67-75.

[15] Nadeem Iqbal, Naveed Ahmad, Zeeshan Riaz, International Letters of Social and Humanistic Sciences 9 (2014) 14-25.

[16] Sakineh Ghayazi, Faranak Omidian, Mohammed Hosseinpoor, International Letters of Social and Humanistic Sciences 10(1) (2014) 51-61.

[17] Morteza Ziaee, International Letters of Social and Humanistic Sciences 10(2) (2014) 172-180.

[18] Gholamreza Jandaghi, Hamid Reza Irani, Ehssan Jandaghi, Zeinab Sadat Mousavi, Maryam Davoodavabi, International Letters of Social and Humanistic Sciences 15(1) (2014) 7-13.

[19] Gholamreza Jandaghi, Hamid Reza Irani, Ehssan Jandaghi, Zeinab Sadat Mousavi, Maryam Davoodavabi, International Letters of Social and Humanistic Sciences 15(1) (2014) 78-83.

[20] Heman Mahmoudfakhe, Morad Abdivarmazan, Toba Amini, International Letters of Social and Humanistic Sciences 15(2) (2014) 84-91.

[21] Sule Maina, International Letters of Social and Humanistic Sciences 4 (2014) 87-96.

[22] Hussein Meihami, Bahram Meihami, International Letters of Social and Humanistic Sciences 5 (2014) 63-72.

[23] Mohamad Khaledian, Galavizh Khaledian, Jabar Sadeghi, Reza Keyhanihekmat, International Letters of Social and Humanistic Sciences 6 (2013) 62-67.

[24] Mohamad Khaledian, Zahra Ahmadimehr, Elham Naseri, Fakhralsadat Khosravani, Mojgan Shoshtsri, International Letters of Social and Humanistic Sciences 8 (2013) 43-48.

[25] Hamid Kamarzarin, Maryam Tehranizadeh, International Letters of Social and Humanistic Sciences 19 (2014) 69-80.

[26] Siamand Movloudi, Heman Mahmoudfakhe, International Letters of Social and Humanistic Sciences 22 (2014) 1-7. 